\title{
Kentsel Arıtma Çamur Uygulamalarının Etkisi : I. Mısır Bitkisi ve Topraktaki Bazı Besin Maddesi (N, P, K, Ca, Mg) İçerikleri Üzerine Etkisi
}

\author{
Hüda Nur ÇAKIR ${ }^{1}$ (D), K.Mesut ÇİMRIN ${ }^{\infty}$ (D) \\ ${ }^{1}$ Hatay Mustafa Kemal Üniversitesi, Fen Bilimleri Enstitüsü, Toprak Bilimi ve Bitki Besleme AnaBilim Dall, Hatay, ${ }^{2}$ Hatay Mustafa Kemal \\ Üniversitesi, Ziraat Fakültesi, Toprak Bilimi ve Bitki Besleme Bölümü, Hatay \\ $\varangle$ : mcimrin@hotmail.com
}

\section{ÖZET}

Bu çalışmanın amacı, artan arıtma çamuru (\% 0, \% 2.5, \% 5, \% 7.5, \% 10) uygulamaları sonrası deneme toprağı ve mısır bitkisinin kök ve kök üstü aksam bazı bitki besin maddesi içerikleri ile mısır bitkisinin verimi üzerine etkilerini incelemektir.

Artan dozda uygulanan arıtma çamurunun etkisiyle deneme toprağının N, P, K ve Ca içeriklerinde istatistiki açıdan önemli, $\mathrm{Mg}$ içeriklerinde ise önemsiz artışlar meydana gelmiştir. Uygulamalar mısır bitkisinin toplam yaş ve kuru verimini tanığa göre tüm uygulamalarda istatistiki açıdan önemli olarak arttırmıştır. Arıtma çamuru uygulamaları mısır bitkisi kök N, P, K, Ca ve Mg içerikleri üzerine etkileri istatistiki olarak çok önemli bulunmuştur. Diğer yandan, artan dozda uygulanan arıtma çamuru mısır bitkisinin kök üstü $\mathrm{N}, \mathrm{P}, \mathrm{K}, \mathrm{Ca}$ ve $\mathrm{Mg}$ içeriklerine istatistiki olarak önemli etkide bulunmuş olup, kök üstü $\mathrm{N}, \mathrm{P}, \mathrm{Ca}$ ve $\mathrm{Mg}$ içeriklerinde tanığa göre önemli artışlar meydana getirmiş ve bu artışlar kök üstü $\mathrm{N}$ ve $\mathrm{P}$ içeriklerinde doğrusal olmuştur.

Sonuç olarak, Hatay ili İskenderun ilçesi evsel biyolojik arıtma tesisinden taze alınan arıtma çamuru ile yapılan çalışmada, her ne kadar arıtma çamuru uygulamaları ile genelde bitki besin elementleri açısından olumlu etkilerde bulunmuş olsa bile, artan arıtma çamuru uygulamaları ile bitki yaş veriminin arıtma çamurunun \% 7.5' luk (AÇ7.5) uygulamasında, bitki kuru veriminin ise arıtma çamurunun \% 5' lik (AÇ5) uygulamasında azalmaya başlaması bu çamurun kontrolsüz bir şekilde ard arda uygulanmaları durumunda zamanla toprakta ve bitkilerde proplemlere sebep olabileceğini göstermektedir.
DOI:10.18016/ksutarimdoga.vi.452930

\section{Makale Tarihçesi}

Geliş Tarihi : 28.03.2018

Kabul Tarihi : 28.05.2018

\author{
Anahtar Kelimeler \\ Toprak, \\ arıtma çamuru, \\ misir, \\ verim, \\ besin elementi içeriği
}

\section{Araştırma Makalesi}

Effect of Municipal Sewage Sludge Applications: I. on some Nutrient Contents (N, P, K, Ca, Mg) of Plant Corn and Soil

\section{ABSTRACT}

The aim of this study was to investigate plant corn yield with some plant nutrient contents of root and shoot and, soil after the increased applications rates of sewage sludge ( $0 \%, 2.5 \%, 5 \%, 7.5 \% 10 \%)$.

The increase in contents of $\mathrm{N}, \mathrm{P}, \mathrm{K}$ and $\mathrm{Ca}$ of the experimental soil was statistically significant while it was insignificant for $\mathrm{Mg}$ by the effect of increased sewage sludge application. The applications resulted in significant increases for the total fresh and dry weight of plant corn compared to the control. It was found that sewage sludge applications affected significantly for the plant nutrient contents of $\mathrm{N}, \mathrm{P}, \mathrm{K}, \mathrm{Ca}$, and $\mathrm{Mg}$. On the other hand, the increased application of sewage sludge resulted in statistically significant changes of plant shoot contents of $\mathrm{N}, \mathrm{P}, \mathrm{K}, \mathrm{Ca}$, and $\mathrm{Mg}$. The shoots contents of $\mathrm{N}, \mathrm{P}$, $\mathrm{Ca}$ and $\mathrm{Mg}$ significantly increased unlinearly compared to the control application while the increases were linear for the shoot $\mathrm{N}$ and $\mathrm{P}$ contents. As a result of this study carried out with fresh sewage sludge taken from biological processing foundation for the housing originated sewage sludge in the iskenderun county of Hatay

\section{Article History}

Received : 28.03.2018

Accepted : 28.05.2018

\section{Keywords}

Soil,

sewage sludge,

corn,

yield,

nutrient content

Research Article 
province, fresh and dry yield decreased by the increased sewage sludge applications of 7.5\% (AÇ7.5) and 5\% (AÇ5) respectively, even though there were somehow positive effects in terms of plant nutrients in general. This suggests that the applications in sequence during the growing seasons under uncontrolled conditions may cause to the problems in plants and soil in time.

To cite: Çakır HN, Çimrin KM 2018. Kentsel Arıtma Çamur Uygulamalarının Etkisi: I. Mısır Bitkisi ve Topraktaki Bazı Besin Maddesi (N, P, K, Ca, Mg) İçerikleri Üzerine Etkisi. KSÜ Tar Doğa Derg 21(6) : 882-890, DOI:10.18016/ksutarimdoga.vi.452930

\section{GíRIŞ}

Birçok ülkede olduğu gibi ülkemizde de belediyelerin atık su arıtma tesislerinde arıtma işlemleri sonucunda kanalizasyon suları temizlenip doğaya verilirken, ne yapılacağı bilinmeyen ve depolanması gün geçtikçe sorun olan büyük miktarlarda arıtma çamurları ortaya çıkmaktadır. Bu çamurların kullanılmasinda yakma, denize veya okyanusa deşarj, arazi dolgusu olarak belirli ve sinırlı olarak veya tarım arazilerine organik madde yada besin elementi kaynağı olarak kullanma gibi çeşitli yöntemler uygulanmaktadır. Ancak, arıtma çamuru miktarının birçok (Nüfus artışı, endüstürileşme, arıtma tesislerinin yaygınlaşması vs.) sebepten sürekli arması yanında gelişen teknolojiye bağlı olarak kanalizasyona dolayısı ile arıtma çamuruna katılan kimyasal madde çeşitliliğinin artarak farklılaşması, arıtma çamurunun bertarafını önemli bir sorun haline getirmektedir.

Uzun zamandır arıtma çamurlarının tarım arazilerine uygulanarak, topraklara ve bitkilere, organik madde ve bitki besin elementi kaynağı olarak değerlendirilmesi üzerinde çalışmalar artarak devam etmektedir (Çimrin ve ark., 2000; Bozkurt ve Çimrin, 2003; Demir ve Çimrin, 2011; Yalçın ve ark., 2011). Ayrica arıtma çamurunun kontrollü koşullarda uygun miktar ve oranlarda toprağa verildiğinde ticari gübrelere ciddi bir alternatif veya destek olacakları çeşitli araştırmacılar tarafından bildirilmektedir (Çimrin ve ark., 2000; Bozkurt ve ark., 2001; Kocaer ve Başkaya, 2001; Yalçın ve ark., 2011).

Arıtma çamurlarının bazılarının tarımsal açıdan olumlu özellikleri yanında doğa ve insan sağlığını tehdit eden olumsuz özellikleri de bulunması bunların tarımda kontürolsüz kullanımını engellemektedir. Olumsuz özelliklerin başında mangan, çinko, bakır, krom, kobalt, nikel, kurşun ve kadmiyum gibi ağır metaller, tuzlar, toksik organik kimyasallar ve hastalık yapıcı mikroorganizmalar sayılabilir. Diğer yandan arıtma çamurlarının hiçbir yerde sürekli yada belli zamanlarda homojen olarak elde edilememesi nedeniyle, gerek doğrudan kullanımlarını gerekse bunlardan ticari bir ürün haline getirilmesini de engellemektedir. Özetle değişik tesislerden çıkan çamurların özelliklerinin farklı olması, çamurun verime etkisini ve kullanım olanaklarını da değiştirebilir. Bu nedenle, arıtma çamurları toprağa uygulanmadan önce mutlaka analiz edilerek içerikleri belirlenmeli ve bu amaçla farklı arıtma çamurları farklı topraklarda denenerek en uygun dozlarının belirlenmesi gerekmektedir.

$\mathrm{Bu}$ araştırmanın amacı Hatay ili İskenderun ilçesi biyolojik evsel atık su arıtma tesisinden alınan taze kentsel arıtma çamurunun tarım toprağına uygulanmasıyla, mısır bitkisinin gelişim ile toprak ve bitkinin bazı besin element kapsamları üzerindeki meydana gelecek değişimleri incelemektir.

\section{MATERYAL ve YÖNTEM}

Çalışmada Hatay' ın Reyhanlı ilçesi, Gazimürsel tepesi mevkii yakınlarındaki tarlalardan alınan yüzey toprakları kullanılırken, arıtma çamuru İskenderun Belediyesi biyolojik evsel atık su arıtma tesislerinden üretimden çıktığı anda bekletilmeden taze ve yaş olarak naylon torbalara konulara aynı gün laboratuvara getirilmiştir. Laboratuvara getirilen arıtma çamuru örnekleri gölgede hava kurusu hale gelinceye kadar sabah akşam karıştırılarak kurutulmuştur. Araştırmada bitki materyali olarak sertifikalı \% 99 çimlenme oranına sahip mısır bitkisinin (Zea mays L.) Pioneer 1570 nolu yazlık melez tohumu kullanılmıştır.

Jackson (1958)' a göre alınan ve analize hazırlanan topraklarda tekstür Bouyoucous (1951)'e göre yapılmıştır. Hem toprak hemde arıtma çamurunda, reaksiyon 1:2.5 toprak veya çamur/su süspansiyonunda Jackson, (1958), total tuz 1:2.5 toprak veya çamur/su süspansiyonunda Richards (1954)' in bildirdiği şekilde elektriki kondaktivimetre aleti ile, kireç Scheibler kalsimetresi ile (Hızalan ve Ünal, 1966), organik madde modifiye edilmiş Walkley Black yöntemi ile (Walkley and Black, 1934), toplam azot Bremner (1965) alınabilir fosfor sodyum bikarbonat ile ekstrakte edilen örneklerde topraklarda renklendirme Mavi (Olsen ve ark. 1954), arıtma çamurunda renklendirme Barton sarı renk yöntemi ile yapılarak spektrofometrede belirlenmiştir (Kacar, 1984). Değişebilir potasyum ve kalsiyum, magnezyum amonyum asetat (1 N) ile çalkalanarak, Kacar (1994)' in bildirdiği şekilde hazırlanan toprak ekstraktlarının mikrodalga plazma atomik emisyon spektrofotometre (MPAES) aletinde belirlenmiştir (Çizelge 1). Arıtma çamurundaki toplam besin elementi ve ağır metal 
analizleri ise yaş yakma ile Khan ve Frankland (1983)'a göre $\mathrm{K}, \mathrm{Ca}, \mathrm{Mg}, \mathrm{Fe}, \mathrm{Zn}, \mathrm{Cu}, \mathrm{Mn}, \mathrm{Pb}, \mathrm{Ni}$, Cd ve Co Atomik Absorpsiyon Spektrofotometresinde belirlenmiştir (Çizelge 1).

Yapılan analizlere göre deneme toprağının killi bünyeli, hafif alkalin reaksiyonlu, tuzsuz, orta kireçli, organik madde içeriğinin orta, azot ve fosfor içeriğinin yeterli, potasyum, kalsiyum ve magnezyum içeriğinin yüksek olduğu belirlenmiştir (Aydeniz, 1985). Deneme toprağının yarayışlı demir, çinko ve mangan içerikleri noksan, bakır içeriği ise yeterli bulunurken (Lindsay ve Norvell, 1978), kurşun, nikel, kadmiyum ve kobalt içerikleri normal sinır değerlerinin altındadır (Özbek ve ark., 1993).

Çizelge 1. Denemede kullanılan toprak ve arıtma çamurunun bazı fiziksel ve kimyasal özellikleri

\begin{tabular}{|c|c|c|c|}
\hline \multicolumn{2}{|l|}{ Toprak özellikleri } & \multicolumn{2}{|c|}{ Arıtma çamuru özellikleri } \\
\hline Kil (\%) & 62.04 & & \\
\hline Silt (\%) & 25.00 & & \\
\hline Kum (\%) & 12.96 & & \\
\hline Tekstür sinıfı & Killi & & \\
\hline $\mathrm{pH}(1: 2.5 \mathrm{su})$ & 7.76 & $\mathrm{pH}(1: 2.5 \mathrm{su})$ & 6.91 \\
\hline Tuz $(\mu \mathrm{s} / \mathrm{cm})$ & 967.5 & $\operatorname{Tuz}(\mu \mathrm{s} / \mathrm{cm})$ & 21060 \\
\hline Kireç (\%) & 13.19 & Kireç (\%) & 9.71 \\
\hline Organik madde (\%) & 1.71 & Organik madde (\%) & 33.8 \\
\hline N (\%) & 0.13 & $\mathrm{~N}(\%)$ & 4.07 \\
\hline Yar. Fosfor (mg/kg) & 12.74 & Yarayışlı P (mg/kg) & 868.51 \\
\hline Değ. K (mg/kg) & 584.0 & Toplam K (mg/kg) & 34800 \\
\hline Değ.Ca (mg/kg) & 4658.7 & Toplam Ca $(\mathrm{mg} / \mathrm{kg})$ & 6900 \\
\hline
\end{tabular}

Arıtma çamuru örneklerine ait bazı kimyasal özelliklerin analizleri verildiği Çizelge 2 incelendiğinde, kullanılan arıtma çamurunun $\mathrm{pH}^{\prime}$ sının hafif asidik, aşırı tuzlu, organik madde içeriğinin yüksek, azot ve fosfor içeriğinin çok fazla, potasyum, kalsiyum ve magnezyum içeriğinin çok yüksek olduğu belirlenmiştir (Aydeniz, 1985).

Deneme dört tekrarlı olarak, tesadüf parselleri deneme desenine göre, beş farklı arıtma çamuru dozunda olmak üzere toplam 20 saksıda Mustafa Kemal Üniversitesi seralarında saksı denemesi olarak yürütülmüştür. Ağırlık ilkesine göre bir kg' lık saksılara \% 0, \% 2.5, \% 5, \% 7.5 ve \% 10 dozlarinda, İskenderun Belediyesi biyolojik evsel atık su arıtma tesisinden taze olarak alınan ve hava kurusu hale getirilen arıtma çamuru uygulanmıştır. Buna göre araştırmada uygulanan deneme konuları aşağıdaki gibi oluşturulmuştur.

1. ACO \% 100 Toprak (Kontrol)

2. AÇ2.5 (\% 97.5 Toprak + \% 2.5 Arıtma Çamuru)

3. AÇ5 (\% 95 Toprak $+\% 5$ Arıtma Çamuru)

4. AÇ7.5 (\% 92.5 Toprak + \% 7.5 Arıtma Çamuru)

5 AÇ10 (\% 90 Toprak + \% 10 Arıtma Çamuru)

Denemede topraklara hava kurusu arıtma çamurları eklendikten sonra saf su ile zaman zaman sulanarak yaklaşık 50 gün inkübasyona bırakılmıştır. İnkübasyon sonunda saksılara sekiz adet tohum ekilmiş ve saf su ile sulanmıştır. Tohum ekiminin 3 . gününde ilk çimlenme görülürken 8 . gününde çimlenme tamamlanmış ve her saksıda dört bitki kalacak şekilde seyreltme yapılmıştır. Temel gübreleme olarak her saksıya $100 \mathrm{mg} / \mathrm{kg} \mathrm{N}, 40 \mathrm{mg} / \mathrm{kg}$ $\mathrm{P}$ ve $40 \mathrm{mg} / \mathrm{kg} \mathrm{K}$ olacak şekilde $18+18+18$ gübresi uygulanmıştır. Deneme boyunca bitkiler saf su ile sulanmış ve tohum ekiminden sonraki kırk sekizinci gün deneme sonlandırılmıştır.

Kurutulup öğütülen bitki kök ve kök üstü aksam örneklerinin bitki besin ve ağır metal analizleri Kacar (1984)'a göre belirlenmiştir.

Çalışmada elde edilen veriler istatistik paket programından yararlanılarak varyans analizine tabi tutularak, etkileri önemli bulunan uygulamalara ait ortalamalar "Duncan çoklu karşılaştırma" testine göre gruplandırılmıştır (Düzgüneş ve ark. 1987).

\section{BULGULAR ve TARTIŞMA}

Uygulamaların hasattan sonra toprağın bazı bitki besin element içerikleri üzerine etkileri:

Deneme topraklarina uygulanan taze aritma çamurunun toprakların toplam azot $(\mathrm{N})$, yarayışh fosfor (P), potasyum (K), kalsiyum (Ca) ve magnezyum $(\mathrm{Mg})$ içeriklerine etkileri ile bunlara ait istatistik değerlendirmeler Çizelge 2 de verilmiştir. Artan düzeyde arıtma çamuru uygulamaları ile toprağın N, P, K ve Ca içerikleri istatistiki olarak \% 0.1 düzeyinde çok önemli olarak etkilenirken, toprakların $\mathrm{Mg}$ içeriklerine etkisi istatistiki olarak önemsiz olmuştur (Çizelge 2). Çizelge 2 incelendiğinde toprağa artan dozda uygulanan arıtma çamurunun etkisiyle, toprağın ortalama N, P, $\mathrm{K}$ ve $\mathrm{Ca}$ içeriklerinde doğrusal olarak artış gözlenmiştir. Toprağın $\mathrm{N}$ değerleri içerisinde en düşük \% 0.15 ile kontrol uygulamasından $\left(\mathrm{AÇ}{ }_{0}\right)$ elde edilirken, artan arıtma çamuru dozlarına bağımlı olarak, $\mathrm{AÇ}_{2.5}$ (\% 0.20), $\mathrm{AÇ}_{5}$ (\% 0.24) uygulamaları aynı Duncan grubuna girerken, $\mathrm{AÇ} 7.5(\%$ 0.30) başka bir grubu, $\mathrm{AÇ}_{10}(\%$ 0.38) diğer başka bir grubu oluş̧urmuştur (Çizelge 2). Uygulamalar ile en düşük 
toprak fosfor içeriği $15.66 \mathrm{mg} / \mathrm{kg}$ ile tanık parsellerden (AÇo) elde edilirken, sırasıyla $\mathrm{AÇ} 2.5$ uygulamasında $72.04 \mathrm{mg} / \mathrm{kg}, \mathrm{AÇ}_{5}$ uygulaması ile $142.44 \mathrm{mg} / \mathrm{kg}$ ve $\mathrm{AC}$ 7.5 uygulamasinda $157.26 \mathrm{mg} / \mathrm{kg}$ ve en yüksek fosfor içeriği $\mathrm{AC}_{10}$ uygulamasından
$200.38 \mathrm{mg} / \mathrm{kg}$ ile elde edilmiştir. $\mathrm{AÇ}_{5}$ ve $\mathrm{AÇ} 7.5$ uygulamaları aynı Duncan grubunda yer alırken, $\mathrm{AÇ}_{0}, \mathrm{AÇ}_{2.5}$ ve $\mathrm{AÇ} 10$ uygulamaları farklı farklı Duncan gruplarını oluşturmuştur (Çizelge 2).

Çizelge 2. Arıtma çamuru uygulamalarının toprağın N, P, K, Ca ve Mg içeriklerine ait ortalama değerleri ile standart hataları ve ortalamalar arasındaki farkı gösteren Duncan grupları ve F değerleri

\begin{tabular}{|c|c|c|c|c|c|}
\hline Uygulamalar & $\mathrm{N}(\%)$ & $\mathrm{P}(\mathrm{mg} / \mathrm{kg})$ & $\mathrm{K}(\mathrm{mg} / \mathrm{kg})$ & $\mathrm{Ca}(\mathrm{mg} / \mathrm{kg})$ & $\mathrm{Mg}(\mathrm{mg} / \mathrm{kg})$ \\
\hline \multicolumn{6}{|c|}{ Arıtma Çamuru } \\
\hline $\mathrm{AÇ} 0$ & $0.15 \pm 0.02 \mathrm{~d}$ & $15.66 \pm 0.09 \mathrm{~d}$ & $408.65 \pm 4.22 \mathrm{~d}$ & $4182.50 \pm 50.73 \mathrm{c}$ & $317.30 \pm 2.18$ \\
\hline $\mathrm{AÇ}_{2.5}$ & $0.20 \pm 0.01 \mathrm{~cd}$ & $72.04 \pm 0.91 \mathrm{c}$ & $457.05 \pm 16.06 \mathrm{c}$ & $4418.12 \pm 72.42 \mathrm{~b}$ & $343.28 \pm 2.38$ \\
\hline $\mathrm{AÇ} 5$ & $0.24 \pm 0.00 \mathrm{c}$ & $142.44 \pm 1.26 \mathrm{~b}$ & $495.38 \pm 24.63 \mathrm{c}$ & $4487.75 \pm 31.91 \mathrm{~b}$ & $366.88 \pm 8.00$ \\
\hline $\mathrm{A} \mathrm{Ç}_{7.5}$ & $0.30 \pm 0.04 \mathrm{~b}$ & $157.26 \pm 5.59 \mathrm{~b}$ & $613.50 \pm 11.17 \mathrm{~b}$ & $4734.32 \pm 45.19 \mathrm{a}$ & $384.60 \pm 3.37$ \\
\hline $\mathrm{A} \mathrm{C}_{10}$ & $0.38 \pm 0.01 \mathrm{a}$ & $200.38 \pm 16.94 \mathrm{a}$ & $772.52 \pm 14.32 \mathrm{a}$ & $4821.95 \pm 47.80 \mathrm{a}$ & $421.28 \pm 56.27$ \\
\hline F değerleri & $20.99 * * *$ & $83.86^{* * *}$ & $87.76^{* * *}$ & $24.88^{* * *}$ & 2.42 \\
\hline
\end{tabular}

$\mathrm{a}, \mathrm{b}, \mathrm{c}, \mathrm{d}$ : aynı harfle gösterilen değerler arasındaki fark önemli değildir $(\mathrm{P}>0.05)$

*** İle gösterilen F değerleri, \% 0.1 düzeyinde önemlidir

Uygulamalar ile en düşük toprak potasyum içeriği $408.65 \mathrm{mg} / \mathrm{kg}$ ile tanık parsellerden (AÇo) elde edilirken, sırasıyla $\mathrm{AÇ}_{2.5}$ uygulamasında 457.05 $\mathrm{mg} / \mathrm{kg}, \mathrm{ACC}_{5}$ uygulaması ile $495.38 \mathrm{mg} / \mathrm{kg}$ ve $\mathrm{ACC}_{7.5}$ uygulamasında $613.50 \mathrm{mg} / \mathrm{kg}$ ve en yüksek potasyum içeriği $\mathrm{AÇ} 10$ uygulamasından $772.52 \mathrm{mg} / \mathrm{kg}$ ile elde edilmiştir. $\mathrm{AC}_{2.5}$ ve $\mathrm{ACC}_{5}$ uygulamaları aynı Duncan grubunda yer alırken, $\mathrm{AÇ}_{0}, \mathrm{AÇ}_{7.5}$ ve $\mathrm{A} \mathrm{C}_{10}$ uygulamaları farklı Duncan gruplarını oluşturmuştur (Çizelge 2). Çizelgede kontrol uygulamasından itibaren toprağın ortalama $\mathrm{Ca}$ düzeyinde düzenli bir artış gözlenmekte olup, en az miktarda kalsiyum AÇo (4182.50 $\mathrm{mg} / \mathrm{kg})$ uygulamasında açığa çıkmış ve artan uygulama miktarlarıyla birlikte $\mathrm{A} \mathrm{C}_{2.5}$ uygulamasında 4418.12 $\mathrm{mg} / \mathrm{kg}$, AÇ5 uygulamasında $4487.75 \mathrm{mg} / \mathrm{kg}, \quad$ AÇ 7.5 uygulamasinda $4734.32 \mathrm{mg} / \mathrm{kg}$ ve $\mathrm{ACC} 10$ uygulamasında $4821.95 \quad \mathrm{mg} / \mathrm{kg}$ değerlerini almışlardır. En yüksek $\mathrm{Ca}$ düzeyi $\mathrm{AÇ} 10$ uygulamasinda meydana gelmiştir. İstatistiksel analizler sonucu $\mathrm{AC}_{2.5}$ dozu ile $\mathrm{AC}_{5}$ dozunun, $\mathrm{AC}_{7.5}$ dozu ile de AÇ10 dozunun aynı Duncan grubuna girdiği görülürken $\mathrm{AÇo} \mathrm{uygulamasının} \mathrm{farklı} \mathrm{bir} \mathrm{grup}$ oluşturduğu gözlenmiştir (Çizelge 2). Artan arıtma çamurunun miktarına bağlı olarak, toprakta alınabilir N, P, K ve Ca miktarlarının artması arıtma çamurunun bu elementler açısından zengin olması ile ilişkili olabilir. Nitekim, faklı iklim ve arıtma çamurları ile çalışan birçok araştırıcı benzer olarak, artan arıtma çamuru ile toprakların N, P, K, Ca ve $\mathrm{Mg}$ içeriklerinin doğru orantılı olarak arttığını ifade etmişlerdir (Çimrin ve ark., 2000; Ünal ve Katkat, 2003; Aşık ve Katkat, 2004; Mazen ve ark., 2010; Yalçın ve ark., 2010; Belhaj ve ark. 2016).
Uygulamaların Mısır Bitkisi Verim, kök ve kök üstü aksam bazı bitki besin element içerikleri üzerine etkileri:

Artan arıtma çamuru uygulamalarının misır bitkisinin (Zea mays L.) toplam yaş ve kuru verim üzerine etkileri Çizelge 3' de verilmiştir. Deneme toprağına uygulanan arıtma çamuru dozlarının mısır bitkisi toplam yaş ve kuru verimleri üzerine etkileri istatistiki olarak $\mathrm{P}<0.001$ düzeyinde çok önemli bulunmuştur. Arıtma çamurunun mısır bitkisi toplam yaş verim ağırlıkları üzerine etkisi incelendiğinde, tanığa göre tüm uygulamaların verimi artırdığı ancak, \% 7.5’ luk arıtma çamuru uygulamasından sonra azalan miktarlara tanık hariç tüm uygulamaları aynı Duncan grubu içerisinde yer almıştır (Çizelge 3). Mısır bitkisi toplam yaş ağırlıkları en düşük $26.53 \mathrm{~g}$ ile tanık uygulamasından $\left(\mathrm{A} \mathrm{C}_{0}\right)$ elde edilirken, artan dozlar ile toplam yaş ağırlıklar sondan bir önceki doza kadar doğrusal olarak artmış $\left(\mathrm{AÇ}_{2.5}: 50.60 \mathrm{~g}\right.$, AÇ5: $53.42 \mathrm{~g}$ ve $\mathrm{AÇ}_{7.5}$ : $56.36 \mathrm{~g}$ ) ve son doz olan AÇ 10 uygulamasında $47.45 \mathrm{~g}$ 'a düşerek azalmıştır.

Çizelge 3' de yer alan toplam kuru verim ağırlıklarına bakıldığında ise toplam yaş verime benzer olarak tanığa göre tüm uygulamaların verimi artırdığı ancak, \% 2.5' luk arıtma çamuru uygulamasından sonra azalan miktarlara tanık ve en son uygulama hariç tüm uygulamaları aynı Duncan grubu içerisinde yer almıştır. Mısır bitkisi toplam kuru ağırlıkları en düşük $3.76 \mathrm{~g}$ ile tanık uygulamasından (AÇ0) elde edilirken, AÇ2.5 dozunda 5.96 g' a yükselmiş ve bundan sonra tanığa göre yükselmesine karşılık diğer dozlar (AÇ ${ }_{5}: 5.86 \mathrm{~g}, \mathrm{ACC}_{7.5}: 5.66 \mathrm{~g}$ ve $\left.\mathrm{AÇ}_{10}: 4.69 \mathrm{~g}\right)$ azalarak artmıştır. 
Çizelge 3. Arıtma çamuru uygulamalarının mısır bitkisi toplam yaş ve toplam kuru verim değerlerine ait ortalama değerleri ile standart hataları ve ortalamalar arasındaki farkı gösteren Duncan grupları ve F değerleri

\begin{tabular}{lll}
\hline Uygulamalar & $\begin{array}{l}\text { Toplam Yaş verim } \\
(\mathrm{g} / \mathrm{bitki})\end{array}$ & $\begin{array}{l}\text { Toplam Kuru verim } \\
(\mathrm{g} / \mathrm{bitki})\end{array}$ \\
\hline Arıtma Çamuru (\%) & & \\
\hline AÇ0 & $26.53 \pm 1.80 \mathrm{c}$ & $3.76 \pm 0.25 \mathrm{c}$ \\
$\mathrm{AÇ} 2.5$ & $50.60 \pm 1.08 \mathrm{ab}$ & $5.96 \pm 0.14 \mathrm{a}$ \\
$\mathrm{AÇ5}$ & $53.42 \pm 4.26 \mathrm{ab}$ & $5.86 \pm 0.40 \mathrm{a}$ \\
$\mathrm{AÇ7.5}$ & $56.36 \pm 2.80 \mathrm{a}$ & $5.66 \pm 0.37 \mathrm{a}$ \\
AÇ10 & $47.45 \pm 1.65 \mathrm{~b}$ & $4.69 \pm 0.16 \mathrm{~b}$ \\
\hline F değerleri & $21.15^{* * *}$ & $10.86^{* * *}$ \\
\hline a, b, c: aynı harfle gösterilen değerler arasındaki fark önemli değildir $(\mathrm{P}>0.05)$ \\
$* * *$ İle gösterilen F değeri, \% 0.1 düzeyinde önemlidir
\end{tabular}

Yapılan Duncan analizinde tanık ve en üst dozlar faklı grupları oluştururken aradaki tüm uygulamalar $\left(\mathrm{A} C_{2.5}, \quad \mathrm{AÇ}_{5}\right.$ ve $\left.\mathrm{AC} \mathrm{C}_{7.5}\right)$ aynı grubu oluşturmuştur. Yapılan farklı çalışmalarda arıtma çamurunun çeşitli bitkiler üzerinde meydana getirdiği etkilere bakıldığında, birçok çalışmada bulgulara benzer sonuçlar rapor edilmiştir. Örnek olarak, Çimrin ve ark. (2000), Triple Süper Fosfat ve arıtma çamuru kombinasyonlarını kireçli bir toprağa fosfor kaynağ olarak uygulamaları sonucu misır bitkisinin bitki kuru ağırlığının kontrol uygulamasına göre önemli ölçüde arttığını bildirmişlerdir. Akat ve ark. (2015) tarafindan Limonium sinuatum 'compindi white' çeşidinde bitki gelişimi, verim ve çiçek kalitesi üzerine arıtma çamuru uygulamalarının bitki verimi üzerine etkileri kontrole göre önemli bulunmuştur. Diğer yandan, bazı çalışmalarda arıtma çamurunun kök yaş ve kuru ağırlıkları üzerine etkilerinin önemli olduğunu bildirirken bazılarında ise önemsiz olduğunu belirtilmiştir. Örnek olarak, Bozkurt ve ark. (2000) kireçli toprakta yetiştirilen mısır bitkisine artan dozlarda arıtma çamuru ve tek dozda humik asit uygulamışlardır. Arıtma çamuru uygulamaları ile mısır bitkisinin kök kuru ağırlığının arttığını bildirmişlerdir. Çimrin ve ark. (2000), Triple Süper Fosfat ve arıtma çamuru kombinasyonlarını kireçli bir toprağa fosfor kaynağı olarak uygulamaları sonucu mısır bitkisinin kök kuru ağırlığının önemli düzeyde değişmediğini bildirmişlerdir. Türkmen ve ark. (2001) kentsel arıtma çamurunun hıyarda çıkış ve fide gelişimi üzerine etkisi üzerine yaptıkları çalışmada, uygulamaların kök yaş ve kök kuru ağırlıkları üzerine olumlu etki yaptığını bildirmişlerdir. Demir ve Çimrin (2011) tarafından arıtma çamuru ve humik asit uyguladıkları mısır bitkisinin gelişimi, besin elementi ve ağır metal içerikleri ile bazı toprak özelliklerini araştırdıkları çalışmada artan dozlarda uygulanan arıtma çamurunun kök aksam yaş ve kuru ağırlıklarını önemli olarak arttırdığı bildirilmiştir. Akat ve ark.
(2017) kesme gül yetiştiriciliğinde bitki gelişimi, çiçeklenme ve kalite üzerine arıtma çamuru uygulamalarının kök yaş ağırlığına etkisi istatistiksel açıdan önemli bulunmaz iken, kök kuru ağırlı̆̆ına etkisinin istatistiksel açıdan önemli bulunduğu bildirmişlerdir.

Arıtma çamuru uygulamalarının mısır bitkisi kök aksam azot $(\mathrm{N})$, fosfor $(\mathrm{P})$ ve potasyum $(\mathrm{K})$, kalsiyum $(\mathrm{Ca})$ ve magnezyum $(\mathrm{Mg})$ içeriklerine ait ortalamaları ile standart hataları ve ortalamalar arasındaki farkı gösteren Duncan grupları ile F değerleri Çizelge 4' da verilmiştir. Arıtma çamuru uygulamaları misır bitkisi kök $\mathrm{N}, \mathrm{P}, \mathrm{K}, \mathrm{Ca}$ ve $\mathrm{Mg}$ içerikleri üzerine etkileri istatistiki olarak çok önemli $(\mathrm{P}<0.001)$ olmuştur (Çizelge 4). Çizelge 4 incelendiğinde toprağa artan dozda uygulanan arıtma çamurunun etkisiyle, bitki kökünün ortalama $\mathrm{N}$ ve $\mathrm{P}$ içeriklerinde doğrusal düzenli artışlar gözlenirken, kök $\mathrm{K}$ içeriği tanıktan sonra ilk dozda düşmüş ancak sonraki dozlarda artmıştır. Kök aksamın artış gösteren $\mathrm{N}$ değerleri içerisinde en düşük \% 1.80 değeri ile kontrol uygulamasında (AÇo) elde edilmiş ve farklı Duncan grubunu oluşturmuşken, artan arıtma çamuru dozlarına bağımlı olarak, $\mathrm{AÇ}_{2.5}$ (\% 2.11) başka bir grubu, AÇ 5 (\% 2.40) ve AÇ7.5 (\% 2.55) uygulamalarının her ikisi başka bir Duncan grubunu oluştururken, $\mathrm{AÇ}_{10}$ (\% 3.06) tek başına farklı bir Duncan gurubunu oluşturmuştur (Çizelge 4).

Artan arıtma çamuru uygulamaları ile en düşük kök aksam P içeriği \% 0.08 ile tanık parsellerden ( $\mathrm{AÇ}_{0}$ ) elde edilirken, sırasıyla $\mathrm{A} \mathrm{C}_{2.5}$ uygulamasında \% 0.09, $\mathrm{AÇ}_{5}$ uygulaması ile \% 0.10, $\mathrm{A} \mathrm{Ç}_{7.5}$ uygulamasında \% 0.10 ve en yüksek fosfor içeriği $\mathrm{AÇ}_{10}$ uygulamasından \% 0.12 ile elde edilmiştir. Yapılan Duncan analizine göre $\mathrm{AÇ}$ o uygulaması bir grubu oluştururken, $\mathrm{AÇ}_{2.5}$ ve AÇ 5 uygulamaları farklı bir grubu, $A C_{7.5}$ uygulaması diğer ve $\mathrm{AÇ}_{10}$ uygulaması bir başka farklı Duncan grubunu oluşturmuştur (Çizelge 4). 
Çizelge 4. Arıtma çamuru uygulamalarının mısır bitkisi kök N, P, K, Ca ve Mg içeriklerine ait ortalama değerleri ile standart hataları ve ortalamalar arasındaki farkı gösteren Duncan grupları ve F değerleri

\begin{tabular}{|c|c|c|c|c|c|}
\hline Uygulamalar & $\mathrm{N}$ & $\mathrm{P}$ & $\mathrm{K}$ & $\mathrm{Ca}$ & $\mathrm{Mg}$ \\
\hline Aritma Çamur & & & $(\%)$ & & \\
\hline $\mathrm{AÇ} 0$ & $1.80 \pm 0.05 \mathrm{~d}$ & $0.08 \pm 0.00 \mathrm{~d}$ & $0.48 \pm 0.00 \mathrm{~b}$ & $0.16 \pm 0.00 \mathrm{c}$ & $0.20 \pm 0.02 \mathrm{~d}$ \\
\hline $\mathrm{AÇ}_{2.5}$ & $2.11 \pm 0.06 \mathrm{c}$ & $0.09 \pm 0.00 \mathrm{c}$ & $0.16 \pm 0.01 \mathrm{e}$ & $0.10 \pm 0.00 \mathrm{~d}$ & $0.24 \pm 0.02 \mathrm{~cd}$ \\
\hline $\mathrm{A} C_{5}$ & $2.40 \pm 0.06 \mathrm{~b}$ & $0.10 \pm 0.00 \mathrm{c}$ & $0.42 \pm 0.00 \mathrm{~d}$ & $0.22 \pm 0.00 \mathrm{~b}$ & $0.28 \pm 0.02 \mathrm{bc}$ \\
\hline $\mathrm{A} C_{7.5}$ & $2.55 \pm 0.04 \mathrm{~b}$ & $0.10 \pm 0.00 \mathrm{~b}$ & $0.44 \pm 0.00 \mathrm{c}$ & $0.21 \pm 0.00 \mathrm{~b}$ & $0.30 \pm 0.02 \mathrm{ab}$ \\
\hline $\mathrm{AÇ}_{10}$ & $3.06 \pm 0.07 \mathrm{a}$ & $0.12 \pm 0.00 \mathrm{a}$ & $0.64 \pm 0.00 \mathrm{a}$ & $0.26 \pm 0.00 \mathrm{a}$ & $0.35 \pm 0.00 \quad \mathrm{a}$ \\
\hline F değerleri & $64.20 * * *$ & $48.61 * * *$ & $514.59 * * *$ & $98.98 * * *$ & $11.26^{* * *}$ \\
\hline
\end{tabular}

a, b, c, d, e: aynı harfle gösterilen değerler arasındaki fark önemli değildir (P>0.05)

*** İle gösterilen $\mathrm{F}$ değerleri, \% 0.1 düzeyinde önemlidir.

Uygulamalar ile misır bitkisi kök aksamında yer alan $\mathrm{K}$ içeriği \% 0.48 ile tanık parsellerden ( $\mathrm{AÇ} \mathrm{C}_{0}$ ) elde edilirken, sirasıyla $\mathrm{AÇ} 2.5$ uygulamasında en düşük K $\% \quad 0.16$, AÇ5 uygulaması ile \% 0.42 ve $\mathrm{AÇ}_{7.5}$ uygulamasında \% 0.44 ve en yüksek $\mathrm{P}$ içeriği $\mathrm{AÇ} 10$ uygulamasından \% 0.64 ile elde edilmiştir. Yapılan çoklu karşılaştırma testine göre tüm uygulamaların hepsi farklı farklı Duncan gruplarinı meydana getirmişlerdir (Çizelge 4). Bulguları destekler nitelikte birçok araştırıcı aşağıda da belirtildiği gibi benzer sonuçları bildirmişlerdir. Örnek olarak, Çimrin ve ark. (2000), Triple Süper Fosfat ve arıtma çamuru kombinasyonlarını kireçli bir toprağa fosfor kaynağı olarak uygulamaları sonucu mısır bitkisinin fosfor içeriğinin, Topçuoğlu ve ark. (2003) toprağa uyguladıkları farklı kentsel arıtma çamurlarının artan dozlariyla domates bitkisinde meydana gelen bitki besin elementi ve ağır metal içeriklerinin değişimlerini araştırdıkları çalışmada arıtma çamurunun artan dozlariyla domates bitkisinin azot, fosfor ve potasyum içeriklerinin arttığını bildirmişlerdir. Ayrıca, Demir ve Çimrin (2011)' in arıtma çamuru ve humik asit uyguladıkları misır bitkisinin gelişimi, besin elementi ve ağır metal içerikleri ile bazı toprak özelliklerini araştırdıkları çalışmada, artan dozlarda uygulanan arıtma çamurunun etkisiyle mısır bitkisinin kök fosfor ve potasyum içeriklerinde önemli artışların saptandığı belirtilmiştir. Akat ve ark. (2017) tarafından kesme gül yetiştiriciliğinde bitki gelişimi, çiçeklenme ve kalite üzerindeki etkilerinde kök aksam azot, fosfor ve potasyum içeriklerinin artan arıtma çamuru uygulamalarıyla artış gösterdiği bildirilmiştir.

Toprağa uygulanan arıtma çamurunun artan miktarları ile bitki kökünde bulunan ortalama $\mathrm{Ca}$ içerikleri \% 0.16 değeriyle $\mathrm{ACÇ}_{0}$ uygulamasında, \% 0.10 değeriyle $\mathrm{AÇ}_{2.5}$ uygulamasında, \% 0.22 değeriyle $\mathrm{AÇ}_{5}$ uygulamasında, \% 0.21 değeriyle $\mathrm{AÇ} 7.5$ uygulamasında ve \% 0.26 değeriyle de $\mathrm{ACC}_{10}$ uygulamasında ortaya çıkmıştır. En yüksek $\mathrm{Ca}, \mathrm{AÇ} 10$ uygulamasında meydana gelmiştir. Yapılan çoklu karşılaştırma testine göre $\mathrm{AÇ}_{0}, \quad \mathrm{AÇ}_{2.5}$ ve $\mathrm{AÇ} 10$ dozlarının her biri farklı Duncan gruplarını oluşturmuş, $\mathrm{AÇ} 5$ ve $\mathrm{A} \mathrm{C}_{7.5}$ ve dozları ise aynı Duncan grubunu oluşturmuşlardır (Çizelge 4). Toprağa uygulanan arıtma çamurunun artan miktarlarının bitki kökünde bulunan kök $\mathrm{Mg}$ içerikleri üzerinde düzenli bir artış gözlenmiş olup, en az miktarda $\mathrm{Mg}$ içerikleri $\mathrm{AÇ}_{0}(\% 0.20)$ uygulamasında açığa çıkmış ve artan uygulama miktarlarıyla birlikte $\mathrm{ACC}_{2.5}$ uygulamasında \% 0.24, AÇ5 uygulamasında \% 0.28, AÇ7.5 uygulamasında \% 0.30 ve $A C_{10}$ uygulamasında $\% 0.35$ değerlerini almışlardır. En yüksek Mg düzeyi $\mathrm{AÇ} 10$ uygulamasında meydana gelmiştir (Çizelge 4). Farklı arıtma çamuru ve farklı bitkilerle çalışan birçok araştırmacı benzer sonuçları bildirmişlerdir. Örnek olarak, Akat ve ark. (2015) Limonium sinuatum 'compindi white' çeşidinde bitki gelişimi, verim ve çiçek kalitesi üzerine arıtma çamuru uygulamalarının bitki kök kalsiyum ve magnezyum içeriklerine önemli etki yaptığını bildirmişlerdir. Akat ve ark. (2017) kesme gül yetiştiriciliğinde farklı dozlarda arıtma çamuru uygulamışlar ve bitki kök aksam kalsiyum ve magnezyum içeriklerinin artan arıtma çamuru uygulamalarıyla artış gösterdiği ve artışın istatistiksel açıdan önemli bulunduğunu bildirmişlerdir.

Artan arıtma çamuru uygulamalarının misır bitkisinin kök üstü aksamlarındaki azot $(\mathrm{N})$, fosfor $(\mathrm{P})$, potasyum $(\mathrm{K})$, kalsiyum $(\mathrm{Ca})$ ve magnezyum $(\mathrm{Mg})$ miktarlarına etkileri Çizelge 5' de verilmiştir. Çizelgenin incelenmesinden de anlaşılacağı gibi araştırma toprağına uygulanan arıtma çamuru dozlarının mısır bitkisi kök üstü aksamlarındaki N, $\mathrm{P}, \mathrm{K}, \mathrm{Ca}$ ve $\mathrm{Mg}$ içerikleri üzerine etkisi istatistiki olarak \% 0.1 düzeyinde çok önemli bulunmuştur. Çizelge 5 incelendiğinde toprağa artan dozda uygulanan arıtma çamurunun etkisiyle, bitki kök üstü aksamının ortalama $\mathrm{N}$ ve $\mathrm{P}$ içeriklerinde doğrusal olarak artışlar gözlenmiştir. Mısır bitkisi kök üstü aksam $\mathrm{N}$ içerikleri içerisinde en düşük \% 1.82 değeri ile farklı bir Duncan grubunu oluşturan kontrol uygulamasından (AÇo) elde edilirken, artan arıtma çamuru dozlarına bağımlı ( $\mathrm{AÇ}_{2.5}, \%$ 2.46; AÇ5, \% 2.85; AÇ7.5, \% 3.28; $\mathrm{AÇ}_{10}, \%$ 3.96) olarak, bütün uygulamalar farklı farklı Duncan gruplarını oluşturmuşlardır (Çizelge 5). 
Çizelge 5. Arıtma çamuru uygulamalarının mısır bitkisi kök üstü aksam N, P, K, Ca ve Mg içeriklerine ait ortalama değerleri ile standart hataları ve ortalamalar arasındaki farkı gösteren Duncan grupları ile F değerleri

\begin{tabular}{|c|c|c|c|c|c|}
\hline Uygulamalar & $\mathrm{N}$ & $\mathrm{P}$ & $\mathrm{K}$ & $\mathrm{Ca}$ & $\mathrm{Mg}$ \\
\hline Arıtma Çamur & & & $(\%)$ & & \\
\hline $\mathrm{A} \mathrm{C}_{0}$ & $1.82 \pm 0.05 \mathrm{e}$ & $0.08 \pm 0.00 \mathrm{e}$ & $1.88 \pm 0.03 \mathrm{~b}$ & $644.52 \pm 8.38 \mathrm{e}$ & $48.87 \pm 1.98 \mathrm{c}$ \\
\hline $\mathrm{A} C_{2.5}$ & $2.46 \pm 0.16 \mathrm{~d}$ & $0.09 \pm 0.00 \mathrm{~d}$ & $1.58 \pm 0.02 \mathrm{~d}$ & $1131.72 \pm 27.22 \mathrm{c}$ & $69.96 \pm 4.30 \mathrm{~b}$ \\
\hline $\mathrm{AÇ}_{5}$ & $2.85 \pm 0.12 \mathrm{c}$ & $0.10 \pm 0.00 \mathrm{c}$ & $1.72 \pm 0.02 \mathrm{c}$ & $1405.59 \pm 19.62 \mathrm{~b}$ & $80.00 \pm 2.32 \mathrm{a}$ \\
\hline $\mathrm{ACC}_{7.5}$ & $3.28 \pm 0.07 \mathrm{~b}$ & $0.12 \pm 0.00 \mathrm{~b}$ & $2.12 \pm 0.05 \mathrm{a}$ & $1018.42 \pm 42.08 \mathrm{~d}$ & $85.20 \pm 2.76 \mathrm{a}$ \\
\hline $\mathrm{AÇ}_{10}$ & $3.96 \pm 0.09 \mathrm{a}$ & $0.14 \pm 0.00 \mathrm{a}$ & $1.98 \pm 0.03 \mathrm{~b}$ & $2234.18 \pm 38.84 \mathrm{a}$ & $82.68 \pm 1.96 \mathrm{a}$ \\
\hline F değerleri & $53.70 * * *$ & $111.22^{* * *}$ & $38.70 * * *$ & $396.62^{* * *}$ & $28.12^{* * *}$ \\
\hline
\end{tabular}

$\mathrm{a}, \mathrm{b}, \mathrm{c}, \mathrm{d}, \mathrm{e}$ : aynı harfle gösterilen değerler arasındaki fark önemli değildir $(\mathrm{P}>0.05)$

$* * *$ İle gösterilen $\mathrm{F}$ değerleri, \% 0.1 düzeyinde önemlidir

Uygulamalar ile en düşük kök üstü aksam P içeriği \% 0.08 ile tanık parsellerden ( $\left.\mathrm{AC}_{0}\right)$ elde edilirken, sirasıyla $\mathrm{AÇ}_{2.5}$ uygulamasında \% $0.09, \quad \mathrm{AÇ}_{5}$ uygulaması ile \% 0.10 ve AÇ 7.5 uygulamasında \% 0.12 ve en yüksek $\mathrm{P}$ içeriği $\mathrm{AÇ} 10$ uygulamasından \% 0.14 ile elde edilmiştir. İstatistiksel analizler sonucu $\mathrm{AÇ}$, $\mathrm{AÇ}_{2.5}, \mathrm{~A} \mathrm{C}_{5}, \mathrm{~A} C_{7.5}$ ve $\mathrm{A} C_{10}$ uygulamalarının her biri farklı farklı Duncan gruplarını oluşturmuştur (Çizelge 5).

Uygulamalar ile mısır bitkisi kök üstü aksamında yer alan K içeriği \% 1.88 ile tanık parsellerden (AÇ ${ }_{0}$ ) elde edilirken, sırasıyla $\mathrm{AÇ}_{2.5}$ uygulamasında en düşük $\mathrm{K}$ $\%$ 1.58, AÇ5 uygulaması ile \% 1.72 ve $\mathrm{AÇ} 7.5$ uygulamasında \% 2.12 ve en yüksek $\mathrm{K}$ içeriği $\mathrm{AÇ} 10$ uygulamasından \% 1.98 ile elde edilmiştir. Yapılan Duncan analizlerine göre $\mathrm{AÇ}_{0}$ ve $\mathrm{A} C_{10}$ uygulamaları aynı Duncan grubunda yer alırken, $\mathrm{AÇ}_{2.5}, \mathrm{AÇ}_{5}$ ve AÇ7.5 uygulamalarının her biri farklı bir Duncan grubunda yer almıştır (Çizelge 5). Toprak organik maddesince fakir olan bu topraklara arıtma çamuru uygulamaları bitkinin N, P ve K alımını olumlu yönde etkilemiştir. Benzer olarak, Bozkurt ve ark. (2001) Van ekolojik koşullarında kışlık arpa bitkisinin azotlu gübre isteğinin inorganik azotlu gübre ve kentsel arıtma çamuru verilerek karşılaştırıldığı denemede, her iki uygulamanında bitki azot içeriğini ve alımını artırdığını fakat, bu artışın arıtma çamuru uygulamalarında daha fazla olduğunu ancak, azot içeriği ve alımı bakımından, inorganik azotlu gübre ve arıtma çamuru uygulamaları arasındaki farkın istatistiki olarak önemsiz bulunduğunu bildirmişlerdir. Ayrıca çalışmada, artan arıtma çamuru dozlarının arpa bitkisi tanesinde fosfor kapsamlarını kontrole göre önemli düzeyde arttırdığını ancak potasyum kapsamına etkisinin önemli olmadığını bildirmişlerdir. Küçükhemek ve ark. (2008) toprağa uygulanan arıtma çamuru, ahır gübresi ve karışımlarının, çim bitkisinin bazı makromikro besin elementleri ve verimine etkisi üzerine yaptıkları çalışmada kontrole göre arıtma çamurunun bitkinin azot, fosfor ve potasyum içeriklerini arttırdığını azot ve potasyum içeriklerinin istatistiksel düzeyde önemli $(\mathrm{P}<0.01)$ olduğu bildirilmiştir. Ahır gübresine göre arıtma çamurunun bitkinin azot ve potasyum içeriklerini artırdığını ve bu artışların önemli $(\mathrm{P}<0.01)$ olduğunu bildirmişlerdir. Demir ve Çimrin (2011) arıtma çamuru ve humik asit uyguladıkları mısır bitkisinin gelişimi, besin elementi ve ağır metal içerikleri ile bazı toprak özelliklerini araştırdıkları çalışmada artan dozlarda uygulanan arıtma çamurunun etkisiyle mısır bitkisinin kök üstü aksam fosfor ve potasyum içeriklerinde önemli artışların saptandığ ifade edilmiştir. Akat ve ark. (2017)' nın bildirdiğine göre kesme gül yetiştiriciliğinde bitki gelişimi, çiçeklenme ve kalite üzerindeki etkilerinde kök üstü aksam azot, fosfor ve potasyum içeriklerinin artan arıtma çamuru uygulamalarıyla kontrole göre artış gösterdiği ve bu artışın istatistiksel açıdan önemli bulunduğu belirtilmiştir. Uygulamalar sonrası bitkinin kök üstünde bulunan ortalama Ca miktarları incelendiğinde de görüleceği gibi toprağa uygulanan arıtma çamurunun artan miktarlarıyla birlikte Ca en az $644.52 \mathrm{mg} / \mathrm{kg}$ değeriyle $\mathrm{AÇ}_{0}$ uygulamasında ve daha sonra $1131.72 \mathrm{mg} / \mathrm{kg}$ değeriyle $\mathrm{ACC}_{2.5}$ uygulamasında, $1405.59 \mathrm{mg} / \mathrm{kg}$ değeriyle $\mathrm{AÇ}_{5}$ uygulamasında, $1018.42 \mathrm{mg} / \mathrm{kg}$ değeriyle AÇ7.5 uygulamasında ve $2234.18 \mathrm{mg} / \mathrm{kg}$ değeriyle de $\mathrm{AÇ} \mathrm{C}_{10}$ uygulamasında ortaya çıkmıştır. En yüksek Ca içeriği AÇ 10 uygulamasında elde edilmiştir. Yapılan çoklu karşılaştırma testine göre tüm uygulamaların her biri ( $\mathrm{A} \mathrm{C}_{0}, \mathrm{~A} \mathrm{C}_{2.5}, \mathrm{~A} \mathrm{Ç}_{5}, \mathrm{~A} \mathrm{Ç}_{7.5}$ ve $\mathrm{A} \mathrm{C}_{10}$ ) farklı farklı Duncan gruplarını oluşturmuşlardır (Çizelge 5). Çizelge 5' de mısır bitkisi kök üstü aksamının $\mathrm{Mg}$ içerikleri sırayla $48.87 \mathrm{mg} / \mathrm{kg}$ (AÇ0), $69.96 \mathrm{mg} / \mathrm{kg}$ $\left(\mathrm{A} \mathrm{C}_{2.5}\right), 80.00 \mathrm{mg} / \mathrm{kg}\left(\mathrm{A} C_{5}\right), 85.20 \mathrm{mg} / \mathrm{kg}\left(\mathrm{AÇ}{ }_{7.5}\right)$ ve $82.68 \mathrm{mg} / \mathrm{kg}\left(\mathrm{AÇ}_{10}\right)$ olarak belirlenmiştir. Yapılan Duncan analiz sonuçlarına göre $\mathrm{AÇ} 0$ ve $\mathrm{AÇ} 2.5$ uygulamaları farklı iki grubu oluştururken, $\mathrm{A} \mathrm{C}_{5}$, AÇ7.5 ve AÇ10 uygulamaları aynı Duncan grubunda yer almıştır.

Ünal ve Katkat (2003) bisküvi ve şekerleme üretimi yapan bir fabrikadan temin ettikleri arıtma 
çamurunu sera koşullarında farklı dozlarda toprağa uygulayarak inkübasyona bırakmışlardır. Bitkide Ca' un kontrole göre doz artışıla paralel şekilde arttığ ve artışın istatistiksel açıdan \% 0.1 düzeyinde önemli bulunduğu bildirilmiştir. Benzer olarak, Demir ve Çimrin (2011) arıtma çamuru ve humik asit uyguladıkları mısır bitkisinin gelişimi, besin elementi ve ağır metal içerikleri ile bazı toprak özelliklerini araştırdıkları çalışmada artan dozlarda uygulanan aritma çamurunun etkisiyle misır bitkisinin kök üstü aksam kalsiyum ve magnezyum içeriklerinde önemli artışların saptandığı ifade edilmiştir. Akat ve ark. (2015) tarafından Limonium sinuatum 'compindi white' çeşidinde bitki gelişimi, verim ve çiçek kalitesi üzerine arıtma çamuru doz uygulamalarının bitki kök üstü kalsiyum ve magnezyum içeriklerine olumlu yönde önemli etki yaptığ ${ }_{1}$ bildirilmiştir. Akat ve ark. (2017) tarafından kesme gül yetiştiriciliğinde bitki gelişimi, çiçeklenme ve kalite üzerindeki etkilerinde kök üstü aksam kalsiyum ve magnezyum içeriklerinin artan arıtma çamuru uygulamalarıyla kontrole göre artış gösterdiği ve bu artışın istatistiksel açıdan önemli bulunduğu belirtilmiştir.

\section{SONUÇ}

Mustafa Kemal Üniversitesi seralarında mısır bitkisi ile saksı denemesi olarak yürütülen çalışmada artan aritma çamuru (\% $0, \% 2.5, \%$ 5, \% $7.5, \%$ 10) uygulamaları sonrası deneme toprağının $\mathrm{N}, \mathrm{P}, \mathrm{K}, \mathrm{Ca}$ ve $\mathrm{Mg}$ içeriklerindeki değişimler ile mısır bitkisinin toplam yaş ve kuru ağırlıkları ile kök ve kök üstü aksamının $\mathrm{N}, \mathrm{P}, \mathrm{K}, \mathrm{Ca}$ ve $\mathrm{Mg}$ içeriklerindeki değişimler incelenmiş̧ir.

Artan dozda uygulanan arıtma çamurunun etkisiyle toprağın $\mathrm{N}, \mathrm{P}, \mathrm{K}, \mathrm{Ca}$ ve $\mathrm{Mg}$ içeriklerinde doğrusal olarak artışlar gözlenmiştir. Uygulamalarla N, P, K ve $\mathrm{Ca}$ içeriklerinde meydana gelen bu artışlar istatistiki açıan çok önemli bulunurken, uygulamaların $\mathrm{Mg}$ içeriğinde meydana getirdiği artışlar istatistiki olarak önemsiz bulunmuştur.

Uygulamalar misır bitkisinin yaş ve kuru verimi üzerinde tanığa göre olumlu etki yapmış ve bu etki istatistiki düzeyde çok önemli bulunmuştur. Artan dozda arıtma çamuru uygulamalarıyla mısır bitkisi kök $\mathrm{N}, \mathrm{P}, \mathrm{K}, \mathrm{Ca}$ ve $\mathrm{Mg}$ içeriklerine etkisi istatistiki açıdan çok önemli bulunmuştur. Arıtma çamurunun artan dozlarda toprağa uygulanmasıyla bitki kökünün $\mathrm{N}, \mathrm{P}$ ve $\mathrm{Mg}$ içeriklerinde doğrusal düzenli artışlar gözlenmiştir.

Artan dozda arıtma çamuru uygulamalarıyla mısır bitkisi kök üstü $\mathrm{N}$ ve $\mathrm{P}$ içeriklerinde düzenli artışlar gözlenmiş, kök üstü $\mathrm{Ca}$ ve $\mathrm{Mg}$ içeriklerinde tanığa göre artışlar meydana gelmiş ve uygulamaların kök üstü $\mathrm{N}, \mathrm{P}, \mathrm{K}, \mathrm{Ca}$ ve $\mathrm{Mg}$ içerikleri üzerine etkisi istatistiki olarak çok önemli bulunmuştur.

Sonuç olarak, Hatay ili İskenderun ilçesi evsel biyolojik arıtma tesisinden taze alınan aritma çamuru ile yapılan çalışmada, her ne kadar arıtma çamuru uygulamaları ile genelde bitki besin elementleri açısından olumlu etkilerde bulunmuş olsa bile, artan arıtma çamuru uygulamaları ile bitki yaş veriminin arıtma çamurunun \% 7.5' luk (AÇ 7.5$)$ uygulamasında, bitki kuru veriminin ise aritma çamurunun \% 5' lik $\left(\mathrm{ACC}_{5}\right)$ uygulamasında azalmaya başlaması bu çamurun kontrolsüz bir şekilde ard arda uygulanmaları durumunda zamanla toprakta ve bitkilerde mineral dengeyi kritik düzeyin üzerine çıkarıp besin dengesini bozarak, çeşitli problemlere sebep olabileceğini göstermektedir.

\section{TEŞEKKÜR}

Yazarlar çalışmaya maddi destek sağlayan Mustafa Kemal Üniversitesi Bilimsel Araştırma Projeleri Koordinatörlüğüne (Proje No: 15880) teşekkür ederler.

\section{KAYNAKLAR}

Akat H, Çetinkale Demirkan G, Akat Ö, Yağmur B, Yokaş, İ 2015. Arıtma Çamuru Uygulamalarının Limonium sinuatum 'Compindi White' Çeşidinde Bitki Gelişimi, Verim ve çiçek Kalitesi Üzerine Etkileri. Ege Üniversitesi Ziraat Fakültesi Dergisi, 52(1): 107-114.

Akat H, Altunlu H, Çetinkale Demirkan G, Akat Saraçoğlu Ö, Yokaş, İ 2017. Kesme Gül Yetiştiriciliğinde Arıtma Çamuru Uygulamalarının Bitki Gelişimi, Çiçeklenme ve Kalite Üzerine Etkisi. Ege Üniversitesi Ziraat Fakültesi Dergisi, 54(3): 327-332.

Aşık BB, Katkat AV 2004. Gıda Sanayi Arıtma Tesisi Atığının (Arıtma Çamuru) Tarımsal Alanlarda Kullanım Olanakları. Uludağ Üniversitesi Ziraat Fakültesi Dergisi, 18(2): 59-71.

Aydeniz A 1985. Toprak Amenajmanı. Ankara Üniversitesi Ziraat Fakültesi Yayınları: 928, Ders Kitabı No: 263, Ankara.

Belhaj D, Elloumi N, Jerbi B, Zouari M, Abdallah F B, Ayadi H, Kallel M 2016. Effects of Sewage Sludge Fertilizer on Heavy Metal Accumulation and Consequent Responses of Sunflower (Helianthus annuus). Environmental Science and Pollution Research, 23(20):20168-20177.

Bouyoucous GD 1951. A Recablibration of the Hydrometer Method for Making Mechanical Analysis of the Soil. Agronomy Journal, 43:434438.

Bozkurt MA, Erdal İ, Çimrin KM, Karaca S, Sağlam M 2000. Kentsel Arıtma Çamuru ve Hümik Asit Uygulamalarının Mısır Bitkisinin Besin İçeriği ve Ağır Metal Kapsamına Etkisi. Tarım Bilimleri Dergisi, 6(4): 35-43.

Bozkurt MA, Yılmaz İ, Çimrin KM 2001. Kentsel Arıtma Çamurunun Kışlık Arpada Azot Kaynağı Olarak Kullanılması. Yüzüncü Yıl Üniversitesi 
Ziraat Fakültesi, Tarım Bilimleri Dergisi, 7(1): 105-110.

Bozkurt, M. A. ve Çimrin, K. M., 2003. Kanalizasyon çamuru uygulamalarının kireçli bir topraktaki besin maddesi ve ağır metal konsantrasyonuna etkisi. Fresenius Environmental Bulletin, 12(11): 1354-1360.

Bremner JM 1965. Total nitrojen. in. C.A. Black et al. (ed). Methods of Soil Analysis. Part 2. Agronomy 9; 1149 - 1178. Am. Soc. of Agron., Inc. Madison, Wisconsin, USA.

Çimrin KM, Bozkurt MA, Erdal İ 2000. Kentsel Arıtma Çamurunun Tarımda Fosfor Kaynağ Olarak Kullanılması. Yüzüncü Yıl Üniversitesi Ziraat Fakültesi, Tarım Bilimleri Dergisi, 10(1): 85-90.

Demir E, Çimrin KM 2011. Arıtma Çamuru ve humik Asit Uygulamalarının Mısırın Geliş̧imi, Besin Elementi ve Ağır Metal İçerikleri ile Bazı Toprak Özelliklerine Etkileri. Tarım Bilimleri Dergisi, 17: 204-216.

Düzgüneş A, Kesici OT, Kavuncu O, Gürbüz F 1987. Araştırma ve Deneme Metodları (İstatistik Metodlari-II). Ankara Üniversitesi Ziraat Fakültesi Yayınları: 1021, Ankara, 381 s.

Hızalan E, Ünal E 1966. Topraklarda Önemli Analizler. Ankara Üniversitesi Ziraat Fakültesi Yayınlar1: 278.

Jackson M 1958. Soil Chemical Analysis. Prentice Hall, Inc. New Jersey. USA.

Kacar B 1984. Bitki Besleme Uygulama Kılavuzu. Ankara Üniversitesi Ziraat Fakültesi Yayınları: 900, Uygulama Kılavuzu: 214, Ankara, 140 s.

Kacar, B., 1994. Bitki ve toprağın kimyasal analizleri: III toprak analizleri. Ankara Üniversitesi Ziraat Fakültesi, Eğitim Araştırma ve Geliştirme Vakfı Yayınları No: 3, Ankara,705 s.

Khan, K. D., Frankland, B., 1983. Chemical froms of $\mathrm{Cd}$ and $\mathrm{Pb}$ in some contaminated soils. Environmental Pollution, 6: 15-31.

Kocaer, F. O. ve Başkaya, S. H., 2001. Arıtma çamurlarının araziye uygulanması. Ekoloji Çevre Dergisi, 11(41): 12-15.

Küçükhemek M, Gür K, Uyanöz R 2008. Toprağa Uygulanan Arıtma Çamuru, Ahır Gübresi ve Karışımlarının, Cim Bitkisinin Bazı Makro-Mikro Besin Elementleri ve Verimi Üzerine Etkisi. Selçuk Üniversitesi Ziraat Fakültesi Dergisi, 22(45): 94-104.
Lindsay, W. L. ve Norvell, W. A., 1978. Development of a DTPA micro nutrient soil test. for $\mathrm{Fe}, \mathrm{Cu}, \mathrm{Zn}$ and Mn. Soil Science Soc. Amer. Proc. 42: 421-428.

Mazen, A., Faheed, F. A., Ahmed, A. F., 2010. Study of potential impacts of using sewage sludge in the amendment of desert reclaimed soil on wheat and jews mallow plants. Brazilian Archives of Biology and Technology, 53(4): 917-930.

Olsen SR, Cole V, Watanabe FS, Dean LA 1954. Estimations of Available Phosphorus in Soils by Extractions with Sodium Bicarbonate. U. S Dept. Of Agric. Cric. 939.

Özbek, H., Kaya, Z., Gök, M., Kaptan, H., 1993. Toprak bilimi. Ç. Ü. Ziraat Fakültesi Genel Yayın No: 73, Ders Kitapları Yayın No: 16, Adana.

Richards LA 1954. Diagnosis and Improvement of Saline and Alkaline Soils. Handbook: 60, U. S. Dept. of Agriculture.

Thomas GW 1982. Exchangeable Cations. Chemical and Microbiological Properties. Agronomy Monography. No: 9, A.S.A.-S.S.S.A., Madison, Winconsin. USA. P. 159-165.

Topçuoğlu, B., Önal, M. K., Arı, N., 2003. Toprağa uygulanan kentsel aritma çamurunun domates bitkisine etkisi I. bitki besinleri ve ağır metal içerikleri. Akdeniz Üniversitesi Ziraat Fakültesi Dergisi, 16(1): 87-96.

Türkmen Ö, Şensoy S, Çırka M 2001. Kentsel Arıtma Camurunun Hıyarda Çıkış ve Fide Gelişimi Üzerine Etkisi. Yüzüncü Yıl Üniversitesi Tarım Bilimleri Dergisi, 11(1): 1-4.

Ünal M, Katkat AV 2003. Bisküvi ve Şekerleme Sanayi Arıtma Çamurunun Toprak Özelliklerine ve Mısır Bitkisinin Kimi mineral Madde İçeriği üzerine Etkileri. Uludağ Üniversitesi Ziraat Fakültesi Dergisi, 17(1): 107-118.

Walkley A, Black LA 1934. An Examination of the Degtjareff Method for Determining Soil Organic Matter and a Proposed Modification of the Chromic Acid titration Method. Soil Sci., 37: 29-38.

Yalçın G, Yavuz R, Taşpınar K, Yılmaz M, Ateş Ö 2010. Eskişehir Atık Su Arıtma Tesislerinden Çıkan Çamurların Farklı Münavebe Sistemlerinde Kullanılması. Tarım ve Köy İşleri Bakanlığı Tarımsal Araştırmalar ve Politikalar Genel Müdürlüğü, Temmuz-2010, s:43.

Yalçın G, Yavuz R, Yılmaz M, Taşpınar K, Ateş Ö 2011. Arıtma Çamurlarının Tarım Alanlarında Değerlendirilmesi. Mühendislik ve Fen Bilimleri Dergisi, Sigma 3: 156-164. 